\title{
Liberal Humanism in a Transforming Post-Apartheid Curriculum of South Africa: An Introspection
}

\author{
Dr Christopher Rwodzi
}

Tshwane University of Technology, Faculty of Humanities, Department of Applied Languages, Pretoria West Campus Email: Christopherrwodzi@yahoo.com/rwodzic@tut.ac.za

Doi:10.5901/mjss.2014.v5n20p1916

\begin{abstract}
South Africa's education history cannot be discussed without mentioning of the multiple languages and plurality of cultures. The 1996 constitution requires education to be transformed and be democratised in accordance with the values of dignity, equality, human rights and freedom, non-racism and non-sexism and guarantees the right to basic education for all. It is in view of the above guiding underpinning principles that this paper seeks to explore the inclusion of liberal humanism as a philosophical perspective in relation to democracy and language education. If we define democracy as a regime dispensation in which all or most adults are men of virtue, the languages are vehicles that carry, translate and educate the innate being of humanity in a growing nation. Humanism is an educational theory that is concerned with enhancing the innate goodness of the individual; therefore the education of South Africa should be a process of developing a free, self-actualising person centred on feelings of the student. In this case, the Bill of Rights in South Africa is no doubt a sign-post and cardinal point for selection of content and capacitating language education in our schools. Curriculum evaluation question why we still have dysfunctional members of society, unemployable people, lack of creativity and corrupt graduates when curriculum should help to culture individuals of the society. Fundamental to the discussion is the aim to discover whether the curriculum is producing skilled people with uneducated minds or vise-versa.
\end{abstract}

Keywords: Liberal humanism and education, curriculum and democracy

\section{Introduction}

Liberal humanism is a cultural position which holds to the essential decency of human beings. It promotes democracy, individualism, tolerance, rationality and civilised values (Dupuis and Hall 2002). This was propounded by people from the middle class. Liberal education consists in studying with the proper care, the great books left behind by the great minds. It can be defined as a philosophical and literary movement in which man and his capabilities are the central concern. In context of historically changing views, it may be the recognizing of the value of the human being as an individual and the right to liberty and happiness. More experienced students/ pupils assist the less experienced including beginners but without simply indoctrinating them. Liberal education is education in culture. It should focus onto perfect gentlemenship to human excellence. The concept liberal means believing that people should have social and political freedom and that they should be allowed to make their own decisions about moral issues. South Africa as a young democracy needs personalities that mentor the young in becoming valuable assets of the state and society. This service can only be available through education. This paper attempts to examine the inclusion of liberal humanism in education through interrogation of curriculum documents. What content and methods are prescribed by the curriculum? What are the ultimate objectives of the curriculum? The philosophy of the state attempts to throw the nation into an identical mould through the schooling system (Barker 1986).

\section{Background}

Hutchins (1899-1977) was a leading voice for education reform in the United States of America. Hutchins like Aristotle and Aquinas was more concerned with cultivating the human person's rational powers. He believed in intellectual excellence and saw earning related to general education, general cultivation of the mind rather than vocational training. Learning was an intellectual effort to come to know the truth about reality. Erasmus (1466-1536) one of the famous Humanist Educators had a good deal of educational insight. In his insights, Erasmus identified four guiding principles:

- Tender mind of the child should be instructed in piety

- Child must love and learn liberal arts 
- He be taught tact in the conduct of social life

- Accustom himself to good behaviour based on moral principles at an early stage

As the guiding philosophy of C2005 in 1997 it was, for its initiators, the pedagogical route out of apartheid education. In its emphasis on results and success, on outcomes and their possibility of achievement by all at different paces and times rather than on a subject-bound, content-laden curriculum, it constituted the decisive break with all that was limiting and stultifying and in the content and pedagogy of education. OBE and C2005 provided a broad framework for the development of an alternative to apartheid education that was open, non-prescriptive and reliant on teachers creating their own learning programmes and learning support materials (DOE, 1997a, b and n.d.) Specifically, it recommended a smaller number of learning areas, including the reintroduction of history, the development of a Revised National Curriculum Statement which would promote conceptual coherence, have a clear structure and be written in clear language, and design and promote 'the values of a society striving towards social justice, equity and development through the development of creative, critical and problem-solving individuals' (Chisholm et al, 2000, viii) The Revised National Curriculum Statement was duly produced and became policy early in 2002. A common demand was the right to private conscience, private enterprise and family values in the context of nation building. This discussion focuses on the inclusion of liberal humanism as a philosophy and awareness among the teachers, education officials and practitioners in as far as its implication to curriculum innovation are concerned. If teachers, parents and administrators understand the concept, what is their role in liberal humanism?

ANC (African National Congress 1996) introduced a modernising, liberal humanist, pragmatic approach to reform the curriculum. This ideology was designed to restore dignity, inculcate values of responsibility and a united front in all affairs of life. The teacher unions on the one hand reasserted the importance of outcomes-based education as foundational philosophy for the post-apartheid curriculum, and on the other established the necessity for a workable and implementable curriculum. They united around the need for a secular, liberal humanist, rights-based curriculum that recognises the diversity of South Africans. What are the teachers doing to achieve the liberal humanistic ambition? Does liberal humanism guide their teaching philosophy?

\section{Literature Review}

\subsection{Liberal Education}

Peters (1960) Liberal education was developed in a number of related philosophical doctrines, about the significance of knowledge and reality. The pursuit of knowledge is thus the pursuit of the good of the mind. Liberal education is essential to man's understanding of how he ought to live both individually and socially. It is developed to accommodate within its scheme new forms of knowledge which includes Christian doctrines and the various branches of modern sciences. However, liberal humanism is not religious education. It is in pursuit of knowledge seeking the development of the mind according to what is quite external to it, the structure and pattern of reality. Baker (1986) says that knowledge is achieved when the mind attains its satisfaction or good by corresponding to objective reality. Objective reality attests to uncontested facts or ultimate knowledge (Leo Strauss 1899). The end product of liberal education is a cultured and integrated human being capable of contributing to society.

\subsection{Liberal humanism should concern itself with three major issues.}

- What is its goal?

- What educational process will most effectively enable it progressively to realise this goal?

- In what kind of an academic community can this process be initiated and sustained?

Liberal humanism prepares the individual so as native endowments permits, to live well in his society and in the universe in which he finds himself (Johnson 1994). That educational process is best which advances us mostly efficiently towards this goal. Liberal education attempts to produce well-disciplined mind, one which is well equipped with basic skills which are in part linguistic as infrastructure for effective communication. South Africa's curriculum complies with this requirement as it provides for the teaching of languages but the only challenge is that African languages are not economically empowered (Mutasa 2006). This leaves them to be least preferred by students when liberalism should be education in culture and one that gives economic freedom. Organisation for Economic Co-operation and Development (2008) states that the medium of instruction is a critical issue in South African Curriculum because of the multiplicity of languages and plurality of cultures. The government of South Africa is well aware that the acquisition of literacy and 
numeracy in the home language for at least four years leads to improved literacy levels. However, most parents prefer their children to be taught in English because it is the language of social and economic mobility. The critical switch from home language to English is not well handled because teachers have little skill to help learners. Culture may be compromised in cases where a foreign language is adopted. Critics may question how education can help provide economic freedom for the nation's citizens? If liberal humanism is education in culture, how is the indigenous culture taught in a foreign language used as medium of instruction? These questions need answers from curriculum planners and if globalisation is part of the answer, therefore our school graduates will have a global culture.

By curriculum, this discussion understands it as the lessons and academic content taught in a school or in a specific course or program with stated aims and objectives. Lawton (1984) defines it as the knowledge and set of skills that students are expected to learn and understand. This program includes the learning objectives that they are expected to meet; the units and lessons that teachers teach; the assignments and projects given to students; the books and materials.

\subsection{Four presumptions of liberal education}

The individual human being is infinitely complex and valuable. It is this complexity evidenced by the fact that he is simultaneously a psycho-physical organism, a social or political animal, a creator of artefacts both utilitarian and artistic. Human beings are also self-conscious thinkers and critics, who are carriers of culture, a responsible moral agent and an immortal soul. Man's innate dignity and value is also basic to our democratic creed (Greene 1966)

Each of us has been profoundly affected since birth by multiple impacts of our immediate family, local community and the nation. We reflect in countless ways, the ideologies and more economic, political social of our society (Dupuis and Hall 2002). The culture and these social institutions themselves are of course the product of countless individuals', men and women. We are very largely what our society and cultures have made us but we in turn can change the values, practices and beliefs of our society and culture thereby modifying the cultural conditions of the coming generations. This culture and social institutions themselves are of course the product of countless efforts by reality definers of the day.

Man and nature do not compromise the whole of reality but that both are rooted and grounded in ultimate reality that transcends space and time and all finite existence. This ultimate reality has been the object of endless metaphysical speculation from time immemorial.

\section{Methodology}

This study used a document analysis approach to gather data about how the South African curriculum attempts the inclusion of liberal humanism in education. Bogdan and Biklen (2003), (Creswell 2007) say that document analysis is a qualitative research methodology, which help researchers by providing factual details such as lists of subjects in schools, schedules of meetings, design of lesson plans and evaluation reports. Documents provide insights into human responses and actions in relation to the national goals of the curriculum. Denzin (1989) Bogdan and Taylor (1975) contend that published articles, administration documents, time tables and teaching notes are sources of data for the qualitative researcher. Researcher analysed documents such as work schedules, aims and objectives of work plans, teacher lesson plans and assessment documents. The researcher analysed documents in pursuit of the inclusion of liberal humanism prevalent in South Africa for curriculum practice. The key question in the investigation is whether liberal humanism is integrated in the curriculum practice in South Africa? If it is included, documents should prove beyond any traceable shadow of doubt that democracy and humanism are implemented in the educational programme and the role of teachers clearly defined.

\section{Findings and Implications for the Curriculum}

What education should aim at is a mind that is able to put the disciplines to its own uses for self-actualisation and preservation. Our Educational aims should be statements of intention to achieve some long term goal. The purpose is to provide an overall direction and orientation towards certain main areas of competence. Our 1996 Constitution guarantees the right of all

South Africans to basic education (Chisholm 2000). The South African Schools Act of 1996 (SASA), which forms the legal foundation for schools in the country, makes schooling compulsory for all learners aged seven to fifteen. Compulsory education is the cornerstone of any modern, democratic society that aims to give all citizens a fair start in life and equal opportunities as adults ( DOE: Plan of Action; Improving Access to free and quality basic education for All 
2003). The idea should be to gather and interpret facts in its own way, to encounter and judge values on its matured responsibility. Our ultimate educational objective is a self-starting, self-criticising and self-nourishing mind, a mind that can function powerfully, creatively and wisely under its own steam. We can promote the mental vitality of our students only by teaching disciplines in a spirit of profound respect for individuality of each student. Barker (1986) says that, It is essential that all that is taught in the school has definite social and practical applicability. There is need to consider the needs of the economy and occupational demand. The skills must enable graduates to find employment, or to be selfreliant. Educational philosophers should give insights on why graduates of a democratised curriculum cannot find jobs or create them in their environment. In this period of transformation, as Jansen points out, the debate was much wider than that in the United States in that the primary criticism came not from fundamentalist Christians who objected to the liberal humanist values of the curriculum, but from academics who analysed its conservative ideological and philosophical assumptions 'bathed in popular education discourse' (Jansen, 1999, p.12), its 'implementational contexts' and 'equity consequences'.

Inclusion of subjects such as Arts and culture, Life Orientation, Languages, Sciences (Both Social and hard Sciences) is a fulfilment of the constitutional obligation and meeting the learners' needs. If Straus (1899) contends that liberal humanism consists of studying with the proper care the great books, he advocate teachers/the experienced in a culture to assist the young and beginners without indoctrinating them. In addition to the teacher standard and strategy of teaching, work must be integrated in the South African context. Learners are given assignments which require them to be creative and solve life problems based on their interests. At grade 10, students are allowed to make subject choices and areas of specialisation depending on their interests as well.

The ANC introduced a modernising, liberal humanist, pragmatic approach to reform. The teacher unions on the one hand reasserted the importance of outcomes-based education as foundational philosophy for the post-apartheid curriculum, and on the other established the necessity for a workable and implementable curriculum. They united around the need for a secular, liberal humanist, rights-based curriculum that recognises the diversity of South Africans. Joblessness can be a signal for curriculum planners to reflect on the content, educational experiences that our schools provide.

Our task as teachers is not to condition animals but to educate human beings and the only educated worthy of man must be focused primarily on that which so signally distinguishes him from all other living beings. We should be aware of intellectualism which tries to divorce the mind from the total personality and which values mental achievement for its own sake.

\subsection{What kind of person should we seek to develop in our schools?}

The personality we should cultivate in our schools and in others is first of all a well disciplined and well integrated one with useful habits well coordinated and with mind and body, reason, emotion instinct and will in harmonious structural relation. Lack of discipline can only result in loss of integration and an unintegrated person is a person at war with himself, frustrated and miserable (Peters 1966). Reports from newspaper articles, department of Education on the lack of discipline by learners in our schools provide an insight into the objectives of the curriculum. The development of a Revised National Curriculum Statement which would promote conceptual coherence, have a clear structure and be written in clear language, and design and promote 'the values of a society striving towards social justice, equity and development through the development of creative, critical and problem-solving individuals' (Chisholm et al, 2000, viii)

Our hope is rather that all men may learn how to be self-creative rather than self-destructive and how to promote human welfare rather than human misery. Only such a personality will process, we believe the creative vitality, worthy of men's highest capacities which are values of humanism.

The social purpose of education must be to prepare young men and women for responsible and cooperative participation in all the overlapping social groups which constitute the structure of our complex society- in the family, in business or profession, in the local community and the nation. Lawton (1984) posits that while the curriculum may not be static, it must be flexible and planners should keep abreast of current trends, and where possible make informed and calculated guesses about the future. Content and its delivery should be within the interest of the students. Students should be at liberty to choose subjects and influence how it should be taught. There was both representation and selection. Selection did occur on the basis of principles rooted in conceptions of South Africa as a diverse society in which the rights of all needed to be recognised. An approach to education about religion rather than education as a form of religious induction prevailed, as did an approach to history which emphasises historical skills and histories denied rather than a narrative of white progress(Chisholm 2003). Minority languages do not get enough support in terms of textbooks and qualified teachers. Consequently, their culture is not taught and education in culture is not possible. While 
the democratic dispensation provide for students to make subject choices at school, their limitation is on the selection of content, methodology and the attitude inculcated by the teachers' strategies and approach.

\section{The Teaching Methods Envisaged}

Dupuis and Hall (2002) contend that the teacher who follows humanistic traditions and theories emphasises learning situations in which each student makes choices. Instruction and assessment is based on student abilities, interest and needs to determine the rules that govern classroom life and they make choices about books to read or exercises to complete. Humanists honour divergent thinking so completely that they delay giving their own personal opinion and do not attempt to persuade students to particular points of view. Practical implications for curriculum implementation dictate that our school teachers use technology in teaching as a way to capture the interests of the learner. If OBE (Outcomes Based Education) was viewed in this perspective by teachers, it could have solved the problem.

\section{Conclusion}

The South African school curriculum promotes the values and ideas on liberal humanism coined in the political philosophy of democracy. Significant strides in the attainment of this goal have been recorded but constraints are still embedded in resolving unemployment rate, creativity and the educated soul that does not cause crime. While some scholars may dispute the philosophy of liberal humanism, it is capable of working to eradicate poverty, crime and unemployment in South Africa and beyond. It can also be a custodian of peace and tranquillity of the nation state.

\section{References}

Baker, R.B (1986) Philosophies of Education. An introduction course. College Press Harare

Bogdan, R and Biklen (2003) Qualitative Research for Education; An introduction to Theories and Practice (4th ed) New York Pearson Education Group

Bogdan, R and Taylor S.J (1975) Introduction to Qualitative Research Methods, New York Wiley -Interscience Chisholm L, 'The State of Curriculum Reform in South Africa: The Issue of Curriculum C2005' in R Southall, A Habib and J Daniel (eds) State of the Nation (HSRC, Pretoria, 2003)

Chisholm, L .2000.South African Curriculum for the Twenty First century Report of the Review committee on Curriculum 2005

Creswell, J.W. (2007) Qualitative Research and Research Design: Choosing among five Approaches. Sage Publications, Thousand Oaks; London.

Department of Education (DOE), Curriculum 2005. Learning for the 21st Century (Pretoria, 1997a)

Department Of Education: Plan of Action; Improving Access to free and quality basic education for All 2003

Denzin N. K (1989) The Research Act: A Theoretical Introduction to Sociological Methods Prentice Hall

Dupuis, V. Hall,D (2002). Introduction to the foundations of American education, 12th Ed. Boston: Allyn \& Bacon.

Greene T.F (1966) Essays on Liberal Humanism

Greene, M. (1978). Wide-awakeness and the moral life. In M. Greene (Ed.), Landscapes of learning. New York: Teacher's College Press.

J. Jansen (1997) 'Why OBE Will Fail' republished in J. Jansen and P. Christie (eds)

(1999) Changing Curriculum: Studies on Outcomes Based Education in South Africa (Juta) as 'Why Outcomes-Based Education will Fail: An Elaboration'

Jansen, J. (1999) The School Curriculum since Apartheid: Intersections of Politics and Policy in the South African Transition Journal of Curriculum Studies 31 (1) 57-67

J. Jansen and P. Christie (eds) (1999) Changing Curriculum: Studies on Outcomes Based Education in South Africa (Juta)

Johnson, E.P (1994) Darwinism Science or Philosophy; Foundation for Thought and Ethics USA

Lawton D (1984) The Politics of the school curriculum London: Routledge and Kegan Paul

Mutasa, D.E. 2006. African languages in the 21st Centuary. The Main Challenges: Pretoria: Simba Guru Publishers.

Organisation for Economic Cooperation and Development report 2008 Pretoria

Peters R (1960) Ethics and Education. London, George Unwin Park (1945) Selected Readings in the Philosophy of Education

South African Schools Act of 1996 Straus L (1899) Leo strauss website 